\title{
The Role of Rehabilitation Program in Functional Recovery of Stroke: A Case Report
}

\author{
Indriani Dwi, Barlian M., Pudji Rosalyna, Lisnaini, Tanian Agung
}

\begin{abstract}
Stroke is a leading cause of functional disorder and severe disability in the world. Stroke prevalence in Indonesia according to national health research (RISKESDAS) in 2007 were $0,8 \%$, meanwhile in United State of America were 1,8-2,2\%. Rehabilitation program had an important role in functional recovery of stroke patient. The purpose of rehabilitation program is to achieve functional independency, minimize disability, re-integration to home, family, and community lifes. The case is a 48 years old male with Left hemiparese due to Cerebrovascular accident intracranial hemorrhage. Initial assesments were Glasgow Coma Scale (GCS) 346, Manual Muscle Testing (MMT) 3 for left upper and lower extremity, Count Breathlessness Test (CBT) 10, Mini-Mental State Examination (MMSE) 22, Barthel Index (BI) 10. The outpatient rehabilitation program was neuromuscular electrical stimulation for left upper and lower extremity with in frequency 70-85 pps, on-time 10-15 seconds, off-time 50 seconds -2 minutes, duration minimum 10 contraction, 3 times per week, active range of motion and isotonic strengthening exercise for upper and lower extremity, breathing exercise, sitting and standing balance exercise, gait training, occupational therapy and cognitive therapy. After 2 months of treatment the assessment was GCS 456, MMT 4 for left upper and lower extremity, CBT 21, MMSE 30, BI 95. The rehabilitation program was proved to be beneficial in improving functional recovery of stroke patient.
\end{abstract}

Keywords: stroke, rehabilitation, electrical stimulation, exercise, functional recovery

\section{INTRODUCTION}

Stroke is permanent damage to areas of the brain that arise suddenly due to blockage of blood vessels or cerebral artery bleeding (Frontera \& DeLisa, 2010). In National Health Research (Riskesdas) 2013, the prevalence of stroke in Indonesia was based on the diagnosis of healthcare providers at 7 per mile and those diagnosed with healthcare providers or symptoms at 12.1 per mile. About $18 \%$ of the body's blood volume with oxygen levels of $20 \%$ circulates in the brain, through two pairs of large blood vessels namely the internal

Revised Manuscript Received on January 2, 2020.

* Correspondence Author

Indriani Dwi*, Department of Physical Medicine and Rehabilitation, Medical Faculty Brawijaya University, dr. Saiful Anwar Hospital, Malang, Indonesia. Email: leo_fery71@yahoo.co.id

Barlian M., Department of Physical Medicine and Rehabilitation, Medical Faculty Brawijaya University, dr. Saiful Anwar Hospital, Malang, Indonesia. Email: barlianikfr@gmail.com

Pudji Rosalyna, Department of Physical Medicine and Rehabilitation, Faculty of Medical Faculty Brawijaya University, dr. Saiful Anwar Hospital, Malang, Indonesia. Email: rosalynahapsari@gmail.com

Lisnaini, MD Doctor, Brawijaya University Malang, Brawijaya University Malang, dr. Saiful Anwar Hospital Malang Physiatrist

Agung Tanian, MD, SpKFR Doctor, Wijaya Kusuma University Surabaya Brawijaya University Malang, dr. Saiful Anwar Hospital Malang Physiatrist carotid artery (anterior) and the vertebral artery (posterior). Both of these circulations form the Willisi circulation at the base of the brain (Islam, 2000). Brain blood flow ranges from 45-60 ml / $100 \mathrm{gr} /$ minute. Reduced cerebral blood flow to below $10 \mathrm{ml} / 100 \mathrm{gr} / \mathrm{min}$, will trigger the loss of ion homeostasis, with the end result being cytotoxic edema. Several factors that influence cerebral blood flow include blood pressure, $\mathrm{O} 2$ and $\mathrm{CO} 2$ levels, blood viscosity, and body temperature (Islam, 2000).

Stroke risk factors consist of two types, namely: (1) modifiable risk factors, namely: lifestyle (diet, smoking, alcohol), hypertension, heart disease, hyperlipidemia, history of TIA, lack of exercise, DM, obesity, high estrogen contraceptive pills; (2) risk factors that cannot be modified, namely: age, sex, race, heredity (Chandra, 1994; Islam, 2000; Bruno-Petrina and Campagnolo., 2012; Harvey and Zorowitz, 2016). The causes of stroke can be divided into two broad categories, namely ischemic and bleeding. Ischemic is the most cause of stroke, which is $80 \%$, while bleeding is 20\% (Bartels, 2004). Indonesian Physical Medicine and Rehabilitation Association (Perdosri) classifies strokes based on the following: Location of anatomic lesions: Cortical, Subcortical, Brain stem. Blockage of blood vessels constitutes $80 \%$ of stroke cases. Some of it is caused by a blockage from the arterial system and a small part is due to a blockage of the brain's venous system. In the age group above 60 years, blockage often occurs in bifurcation of the carotid artery; whereas in younger age groups, the most common cause is thrombus emboli originating from the heart or aorta and its main branches (Islam, 2000; Harvey and Zorowitz, 2016).

Trias Virchow states that thrombus is formed when there is (1) damage to blood vessels, often caused by severe and prolonged hypertension, DM, inflammation, and others. (2) obstruction of blood flow, and (3) impaired blood coagulation, the most common cause is platelet hyperaggregation (Islam, 2000; Harvey and Zorowitz, 2016). The pathophysiology of stroke due to thrombosis is controversial, but there is a strong association with cerebral atherosclerosis. Atherosclerotic plaque often occurs in chronic hypertension, with trauma to the intima layer followed by macrophage infiltration and cholesterol accumulation in the media layer (Subadi, Subagyo and Andriana, 2008). 


\section{The Role of Rehabilitation Program in Functional Recovery of Stroke: A Case Report}

Microembolism are produced from cerebral thrombus of the brain. Thrombus formation is due to structural and mechanical factor in the heart. Atrial Fibrillation is one of risk factor for embolism (Subadi, Subagyo and Andriana, 2008).

The diagnosis of stroke is based on history taking, physical examination and supporting examination (Islam, 2000).

From the history can be explored the main complaints, current illness, past illness, activity, treatment, social, family, and review of its system (Cifu, 2015). Anamnesis obtained from patients and families in a complete and thorough. Anamnesis about the onset of events, the course of the disease that leads to bleeding strokes or infarction, the history of the disease first, as well as the risk factors underlying the onset of a stroke. Psychosocial and vocational history also needs to be explored for the management of patients as a whole (Islam, 2000; Subadi, Subagyo and Andriana, 2008).

From physical examination in general, it must be explored about organ systems including, heart, lungs, and abdomen (Cifu, 2015). Then from neurological examination can be explored: Cognitive function, Communication, Examination of cerebellar function, cranial nerve examination, Sensation - includes ecstrospective (pain, touch, temperature), proprioception (movement, position, vibration), interoseptif (taste, odor), and cerebral sensory function (graphesthesia, stereognosis, two- point discrimination), Motor control and reflexes - physiological and pathological reflexes. (Campbell \& DeJong, 2009; Gruener \& Brazis, 2011; Cifu, 2015). Musculoskeletal examination can also be done by exploring the presence of deformity, joint stability, joint motion area (active and passive), muscle strength, and joint / muscle pain (Cifu, 2015). Supporting examinations that can be done include CT scans and MRI of the head. The medical rehabilitation program is very instrumental in restoring the function of stroke patients. The medical rehabilitation program is aimed at achieving a degree of functional independence, minimizing disability, reintegration into the home, family and community and rebuilding a meaningful and satisfying life. This is never the same for every patient and must be planned individually (Bartels, 2004).

\section{CASE REPORT}

The case is 48 years old male with left hemiparese due to Cerebrovascular accident intracranial hemorrhage. Initial assesments were Glasgow Coma Scale (GCS) 346, Manual Muscle Testing (MMT) 3 for left upper and lower extremity, Count Breathlessness Test (CBT) 10, Mini-Mental State Examination (MMSE) 22, Barthel Index (BI) 10. The outpatient rehabilitation program was neuromuscular electrical stimulation for left shoulder flexor-abductor, elbow flexor, wrist extensor, finger flexor and left hip extensor, knee extensor, ankle dorsoflexor within frequency 70-85 pps, on-time 10-15 seconds, off-time 50 seconds -2 minutes, duration minimum 10 contraction, 3 times per week. active range of motion and isotonic strengthening exercise for upper and lower extremity, breathing exercise, sitting and standing balance exercise, gait training, occupational therapy and cognitive therapy. After 2 months of treatment the assessment was GCS 456, MMT 4 for left upper and lower extremity, CBT 21, MMSE 30, BI 95.

\section{RESULT AND DISCUSSION}

An acute stroke is a medical emergency. In an ischemic stroke, the penumbra region, which is an ischemic area around a dead brain tissue, will also experience infarction within 4-6 hours later. This time interval is a golden period in the management of ischemic stroke. The main problem in bleeding strokes is increased intracranial pressure which can cause brain herniation (Islam, 2000; Harvey and Zorowitz, 2016). General therapy for stroke refers to $6 \mathrm{~B}$, namely: Breath, Blood, Brain, Bowel, Bladder, Bone and Body skin, breath, maintained that the respiratory function and oxygenation remain good, if needed can be given oxygen. Blood pressure should be monitored every 2-4 hours, also pay attention to blood sugar levels. Hyperglycemia can cause widespread damage to brain cells due to lactic acidosis. The patient's conscious function should always be monitored every 2-4 hours, also signs of increased intracranial and neurological function. It should be noted also the function of the bowel and bladder, gastrointestinal bleeding often occurs due to stress ulcers. The condition of bone and body skin should not go unnoticed because of the prolonged immobilization in stroke patients (Poerwadi, 1993; Widjaja, 1993; Islam, 2000). Early rehabilitation programs aim to maximize the potential for improvement or cure and prevent complications as early as possible due to prolonged immobilization (Poerwadi, 1993; Subadi, Subagyo and Andriana, 2008).

Stroke is one of the diseases witch cause most disability and death. The mortality rate in strokes ranges from $20-30 \%$ even in bleeding strokes reaching $40 \%$. The most common cause of death in the first week is due to trans-tentorial herniation, while the cause of death after the first week is often caused by non-neurological factors, including pneumonia, embolism and sepsis (Islam, 2000). Some studies say that $48-58 \%$ of patients will return to self-care independence. $75-85 \%$ of patients will reach a level of independence by ambulation using canes or other walking aids. Nearly all patients can control bladder and bowel, and only 10-29\% patients suffer from severe disability and prolonged bed rest (Zorowitz et al., 2004). Factors that influence the prognosis of stroke patients include: (1) age, (2) health condition of the patient before illness and physical factors of the patient (3) type of stroke and severity of damage when the patient arrives (awareness, extent of bleeding, intra cranial pressure, complications), (4) rapid and appropriate treatment, and disease progression (Widjaja, 1993; Zorowitz et al., 2004) 


\section{BI Graph}

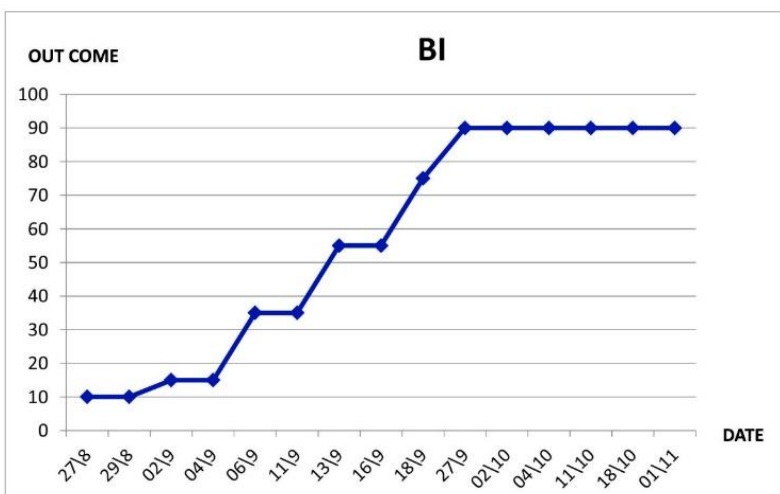

Figure 1. Progression of Barthel Index

CBT Graph

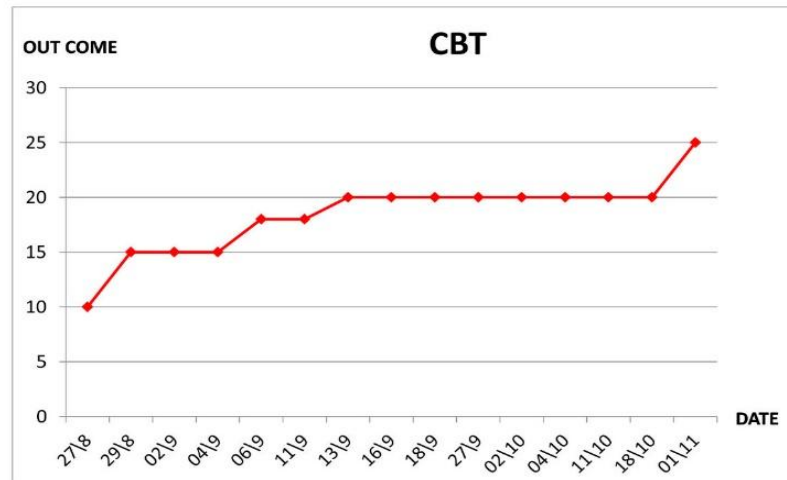

Figure 2. Progression of Count Breathlessness Test

GCS Graph

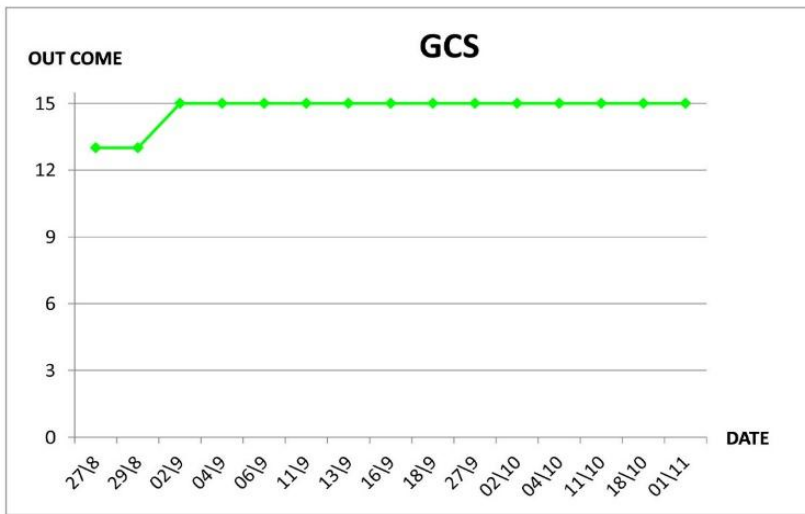

Figure 3. Progression of Glasgow Coma Scale

\section{MMT Graph}

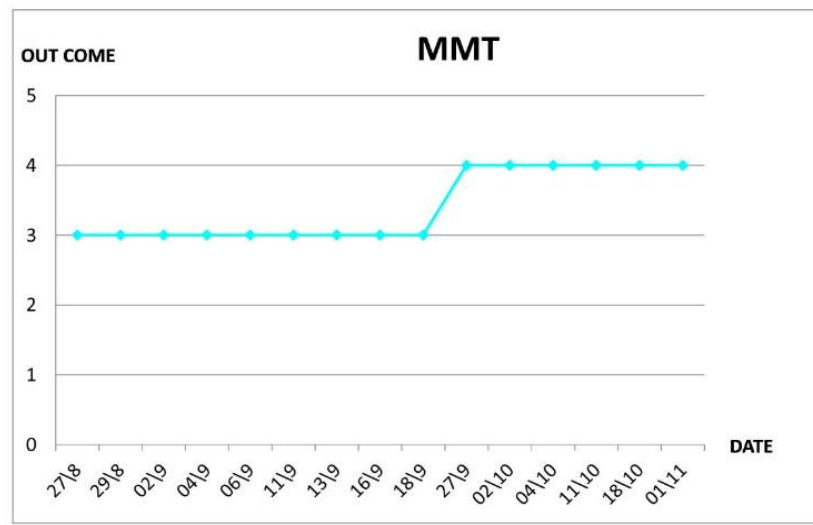

Figure 4. Progression of Manual Muscle Testing

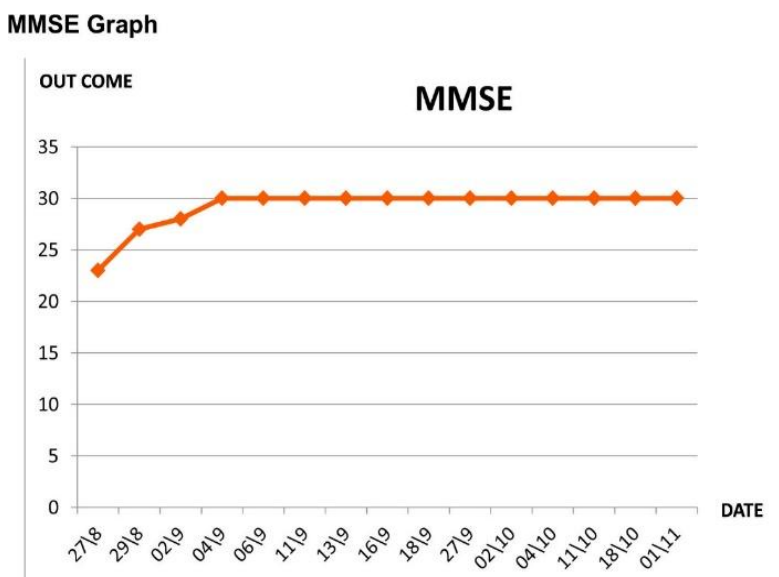

Figure 5. Progression of Mini Mental State Test

\section{CONCLUSION}

The medical rehabilitation program is very important in restoring the function of stroke patients. The medical rehabilitation program is aimed at achieving a degree of functional independence, minimizing disability, reintegration into the home, family and community and rebuilding a meaningful and satisfying life. This is never the same for every patient and must be planned individually.

\section{ACKNOWLEDGMENT}

The author would thanks to staff of Department Physical Medicine Rehabilitation to give support to authors for treathing this stroke patient

\section{REFERENCES}

1. Bruno-Petrina A and Campagnolo DI. 2012. Motor Recovery In Stroke Available at: www.emedicine.com. Dowloaded on December 4th, 2017.

2. Islam MS, 2000. Stroke: Diagnosis and Management. Hand out of Neurology Lecture. Surabaya: Neurology Department of Airlangga Medical Faculty Dr.Soetomo Hospital (in Indonesian)

3. Chandra B, 1994. Clinical Neurology. Revised Edition. Neurology Department of Airlangga Medical Faculty Dr.Soetomo Hospital, pp28-46. (in Indonesian)

4. Cifu, D.X. 2015. Braddom's Physical Medicine and Rehabilitation 5th Edition. Elsevier Health Sciences.

5. Campbell, W.W. and DeJong, R.N. 2009. DeJong's the Neurologic Examination (No. 2005). Lippincott Williams \& Wilkins.

6. Gruener, G. and Brazis, P. 2011. DeMyer's the Neurologic Examination: A Programmed Text. McGraw-Hill Professional.

7. Frontera, W.R. and DeLisa, J.A. 2010. Physical Medicine and Rehabilitation. Lippincott Williams \& Wilkins Health.

8. Sofyan, A.M., Sihombing, I.Y. and Hamra, Y. 2015. Relationship of Age, Gender, and Hypertension with Stroke. Medula, (in Indonesian)

9. Ministry of Health. 2013. National Health Research 2013. Research and Health Development Agency, Ministry of Health, Indonesia. (in Indonesian)

10. Harvey RL and Zorowitz RD 2016. Stroke Syndromes. In: Braddom RL (Ed). Physical

11. Medicine and Rehabilitation. 5th ed. Philadelphia: Elsevier Saunders, pp 999-1015.

12. Bartels MN, 2004. Pathophysiology and Medical Management of Stroke. In (Burkhardt A \& Gillen G eds). Stroke Rehabilitation-a Function Based Approach. 2nd Edition, St. Louis, Missouri: Mosby, pp 1-30.

13. Subadi I, Subagyo dan Andriana M, 2008. Vascular Disorder of Brain Diagnosis and Therapy Guideline from Functional Medic Staff of Medical Rehabilitation. $1^{\text {st }}$ Edition. Surabaya: Medical Rehabilitation of Dr.Soetomo Hospital, pp 20-24. (in Indonesian)

14. Brandstater ME, 2010. Stroke Rehabilitation. In: Delisa JA et al (Ed). Physical Medicine and Rehabilitation. 5th Edition. Philadelphia: Lippincot Williams \& Wilkins, pp 551-74. 
15. Poerwadi T, 1993. Vascular Disorder of Brain Treatment. Neurology Series. Surabaya: Neurology Department of Airlangga Medical Faculty Dr. Soetomo Hospital. (in Indonesian)

16. Widjaja L, 1993. Pathophysiology and Treatment of Stroke. Neurology Series. Surabaya: Neurology Department of Airlangga Medical Faculty Dr. Soetomo Hospital. (in Indonesian)

\section{AUTHORS PROFILE}

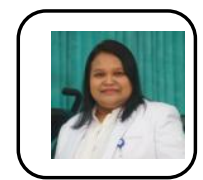

Dwi Indriani, MD, SpKFR is a Physiatrist who received her medical doctor on Brawijaya University Malang and become a physiatrist on Airlangga University Surabaya. Now she work as a staff on dr. Saiful Anwar Hospital Malang. She is an active member of ISPRM (International Society of Physical \& Rehabilitation Medicine) and PERDOSRI (Perhimpunan Dokter Spesialis Rehabilitasi Medik Indonesia).

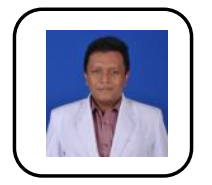

M. Barlian, MD, SpKFR is a Physiatrist who received his medical doctor on Brawijaya University Malang and become a physiatrist on Airlangga University Surabaya Now he work as a staff on dr. Saiful Anwar Hospital Malang. He is an active member of ISPRM (International Society of Physical \& Rehabilitation Medicine) and PERDOSRI (Perhimpunan Dokter Spesialis Rehabilitasi Medik Indonesia).

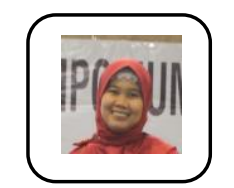

Rosalyna Pudji, MD, SpKFR is a Physiatrist who received her medical doctor on Airlangga University Surabaya and become a physiatrist on Airlangga University Surabaya. Now she work as a staff on dr. Saiful Anwar Hospital Malang. She is an active member of ISPRM (International Society of Physical \& Rehabilitation Medicine) and PERDOSRI (Perhimpunan Dokter Spesialis Rehabilitasi Medik Indonesia).

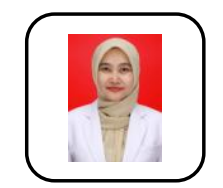

Lisnaini, MD is a General Practitioner who received her medical doctor on Brawijaya University Malang. Now she is in residency of Brawijaya University Malang at dr. Saiful Anwar Hospital Malang to be a Physiatrist

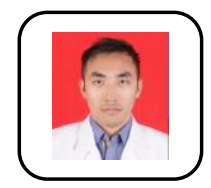

Agung Tanian, MD, SpKFR is a General Practitioner who received his medical doctor on Wijaya Kusuma University Surabaya. Now he is in residency of Brawijaya University Malang at dr. Saiful Anwar Hospital Malang to be a Physiatrist 